\title{
THE IMPACT OF INFORMATION
} TECHNOLOGY INVESTMENTS ON FIRM PERFORMANCE IN NATIONAL AND MULTINATIONAL COMPANIES

\author{
*Cemal ZEHIR \\ *Busra MUCELDILI \\ *Bulent AKYUZ \\ *Ali CELEP \\ *Gebze Institute of Technology, Turkey
}

\begin{abstract}
The aim of this study is to research the relationship between information technology (IT) investment level, IT usage, IT perception, IT at decision making process, future orientation, technology orientation and firm performance in the comprehensive competitive environment. According to this aim, we researched the related literature and after developing a research model and hypotheses, we made numerous analyses. The data of this study were obtained from a sample of different National and Multinational Companies in Turkey. 158 firms were given the questionnaire which traded on ISE( Istanbul Stock Exchange) and 94 have answered and returned it, we narrowed our sample with 81 firms which really answered correctly and carefully. In accordance with literature, the findings of this study showed that IT investments are vital component of firm performance. If firms manage IT investments successfully, they will enhance firm performance. Moreover, the study enlightens not only the practitioners but also the academicians for the future researches.
\end{abstract}

Key Words: Firm performance, Information technology, Information technology investment, Technology orientation, Future orientation.

\section{INTRODUCTION}

Based on literature on management strategy, unique resources in a firm played role for competition (Huang, Ou,Chen, Lin, 2006). Information technology (IT) can be accepted as a unique resource in a firm in the ends of the 20th century and 21th century. According to Grant, IT- based resources can be classified as: tangible resorces that comprising the physcial IT infrastucture components, human IT resources that comprising the technical and managerial IT skills, and intangible IT resources, such as knowledge assets, customer orientation and synergy. The long term survival of firms is closely related to their ability to successfully managed information technologies (IT) in today's harsh and rapidly changing business environment. IT is the fastest growing sector in the economy, with 68 percent increase in output growth rate projected between 2002 and 2012 (Callahan, Gabriel and Smith, 2009). And corporations have invested billions of dollars in information technology (IT) over the last 20 years (Ta Byrd, Te Marshall; 1997). The reason of this growth is due to three factors. First, IT is no longer primarily confined to backroom operations. As Ceo of Wal-Mart says, "At Wal -Mart and at many other companies, technology has become integrated with every aspect of the business." Second, the role of CIO has been elevated from the back office to the board room and companies now emphasize the ability of CIOs to contribute beyond IT functionality. Third, the use 
and misuse of IT has become fertile ground for an ever increasing number of oppurtinities to either gain a competitive advantage or fall into a position of competitive disadvantage (Dehning, Richardson, Staratpoulo,2005). So manufacturer and service organizations must follow IT trend. This trend is about investments to hardware and software and globalization to the information technology networks (Wen\&Sylia, 1999).

Despite the substantial investments in IT by corparations, direct linkage between technology investment and increases in productivity and performance has been extremely elusive. Anticipated benefits from technology investments include reduced costs, improved quality, increased flexibility, improved customer satisfaction, higher productivity and ultimately, higher financial performance. Because of the enormous expenditures on IT by today's organizations, researchers and practitioners through investigation, are seeking to understand better the relationship between IT and performance. To determine this relationship, researchers must discover the relationship between IT and organizational performance (Ta Byrd, Te Marshall; 1997). Although, for over a decade, the researchers have studied the impact of IT investments on firm performance, studies are inconsistent (Yao, Sutton, Chan, 2009). Some studies have found positive relationship between IT investments and performance, other studies found a negative relationship, and numerous other studies showed no relationship (Ta Byrd, Te Marshall; 1997).

To overcome this perplexing situation, many IT scholars have used more rigirous and scientific research framework; large sample datasets, including additional factors such as a time lag, the information intensity of the industry, new methodology and new theories (Kim, Xiang, Lee, 2009). Moreover, the relationship between IT and firm performance differs from developing countries to developed countries. Because, economic growth, regulation levels, labor costs, IT skills and availability, and heterogeneity, competition, complementary organizational innovations and culture can be different across countries (Kim, Xiang, Lee, 2009). Therefore, the primary purpose of this paper is to investigate the relationship between IT investments and organizational performance as technology orientation and future orientation concept in IT investments in Turkey.

\section{LITERATURE REVIEW AND DEVELOPMENT OF THE HYPOTHESES}

In this study, we investigated the relationship between firm performance and IT investments. The effect of IT can be seen at different levels of analysis that include individuals, groups, organizations, industires and societies. The level of analysis in this study is at the organizational level. This research investigates the behaviours of employee and managers who establish the long term interaction between information technologies and firms.

According to this aim, the related literature was researched, the research model and hypotheses were developed, and numerous analyses were made.

\section{Information Technology Investments}

According to economical view, IT is an input in the production process and there is an interaction between IT and other inputs. Thus, IT provides benefit to the organizations more than capital and labour. IT's benefits can be evaluated at the organizational, industrial and nation level (Hu\& Quan, 2004). For providing performance, organizations should invest and coordinate IT effectively (RMS,2008). 
In this study the factors affecting firm performance have been analyzed under four main topics. These are IT investment level, IT usage, IT perception and IT at decision making process. At the first stage, we made a study of the effects of these four factors on technology and the future orientation, whereas we studied the effects of technology and future orientation on firm performance at the second stage.

IT enables the tranformation of organizations activating on different industrial branches to associated marketing firms, whilst universalizing the strategical unions among the enterprises (Iraz, R, 2008). IT investments have an impact on economical growth. In consequence of consistent innovation and the usage of technology, new processes can be developed and product outcomes can be increased (Artzeni\&Carboni, 2001). Information technologies set up communication platforms on the world by connecting people and gain access to precise information by means of World Wide Web (Kraut, 1998).

H1: There is a relationship between IT investment level and firm performance.

Firms make the description of the daily problems confronting in their activities by using IT. IT usage guides to formulize the policies which will stimulate the economical growth and development. It also provides very significant foresights for the rule regulators working on the field of specific sector development (Esselaar, 2006). Product quality standards continue to increase regularly with the usage of IT. The computer supported designing models increase the performance of machines and products by using advanced simulation technics. It also decreases the levels of tolerance during production process through effectively set up feedback mechanisms (Iraz, R, 2008).

$\mathrm{H} 2$ : There is a relationship between IT usage and firm performance.

In context of technology, the perception of technology is different individual to individual. According to Technology Admit Model (TAM) while individuals decide to accept or refuse the new technology, they focus on facility usage and effectiveness. A person's degree of belief on using the system easily or difficultly can be defined as a facility usage (Davis, F.D, 1986).

H3: There is a relationship between IT perception and firm performance.

Decision-making process is the most important role of a manager in organizations, because survival of organizations depend on the managers' decisions. For example, a manager can acquire the information which is necsseary for production process by complex ERP system or simple software matrix programme (Tanoğlu and Basoğlu, 2005).

H4: There is a relationship between IT at the decision making process and firm performance.

A future orientation firm gives particular importance to the potential customers and competitors beside the current customers and competitors. Future orientation firm considers both the future market and its customers, competitors and current customers' needs (Chandy and Thelis, 1998).

H5: There is a relationship between future orientation and firm performance.

H6: There is a relationship between IT at the decision making process and future orientation.

H7: There is a relationship between IT investment level and future orientation.

H8: There is a relationship between IT perception and future orientation.

H9: There is a relationship between IT usage and future orientation. 
Technology can be conceptualized as a subunit strategic of sources used by a firm on present and future innovation efforts. High firm performance depends on the technological proficiency of the firms.Unless a firm predicts and follows the technological developments and use these developments for the improvement of its own product and process, high firm performance may not come true (Freeman and Soote, 1997; Meesuus and Oerlemans).

H10: Ther is a relationship between technology orientation and firm performance.

H11: There is a relationship between IT at the decision making process and technology orientation.

H12: There is a relationship between IT investment level and technology orientation.

H13: There is a relationship between IT perception and technology orientation.

H14: There is a relationship between IT usage and technology orientation.

\section{Firm Performance}

There are several definitions of firm performance in the literature but the simplest definition is to measure productivity (Zehir, Yılmaz, Velioğlu,2008). Performance is generally stated as a doing business, implementing successfully. Performance, the main criteria of measuring success, could be defined as quite a wide concept that evaluates the ability to achieve the organization's targets successfully (Akal; 1994).

Performance can be evaluated with qualitative criteria such as job satisfaction, organizational commitment, perception of justice and quantitive criteria such as profitability, investment return ratio, sales growth in the studies. In this study, quantitive criteria such as financial, market and innovation performance is used. Financial performance measure the organization's basic economical targets, and these targets are important for practitioners and researchers; therefore in the studies, financial performance is used commonly. Profitability, revenue, investments' return ratio are used commonly in the studies and they are called financial performance evaluation criteria.

In addition to financial performance, market performance is important, too. Market growth and sales growth are important for practitioners and researchers, too. Customer satisfaction and commitment, change in market share, communication with customers by advertising or sales are used commonly in studies as market performance criteria. Because of the rapid change in the demands and needs of customers, the product life get shorter. To handle this problem, firms must make radical innovations (Hunt, Morgan,1996).

So, practitioners and academicians began to study about innovation concept. They made field study and developed appropriate measure criteria. The innovation performance criteria are about the R\&D rate in the firm's budget, the new products, the new projects, the quality of the new projects and new products.

In our research, with the guidelines of literature review and previous empirical research, a research model has been developed to predict effects of IT investment level, IT usage, IT perception and IT at the decison making process and future orientation and techology orientation on firm performance. The research model is presented below: 


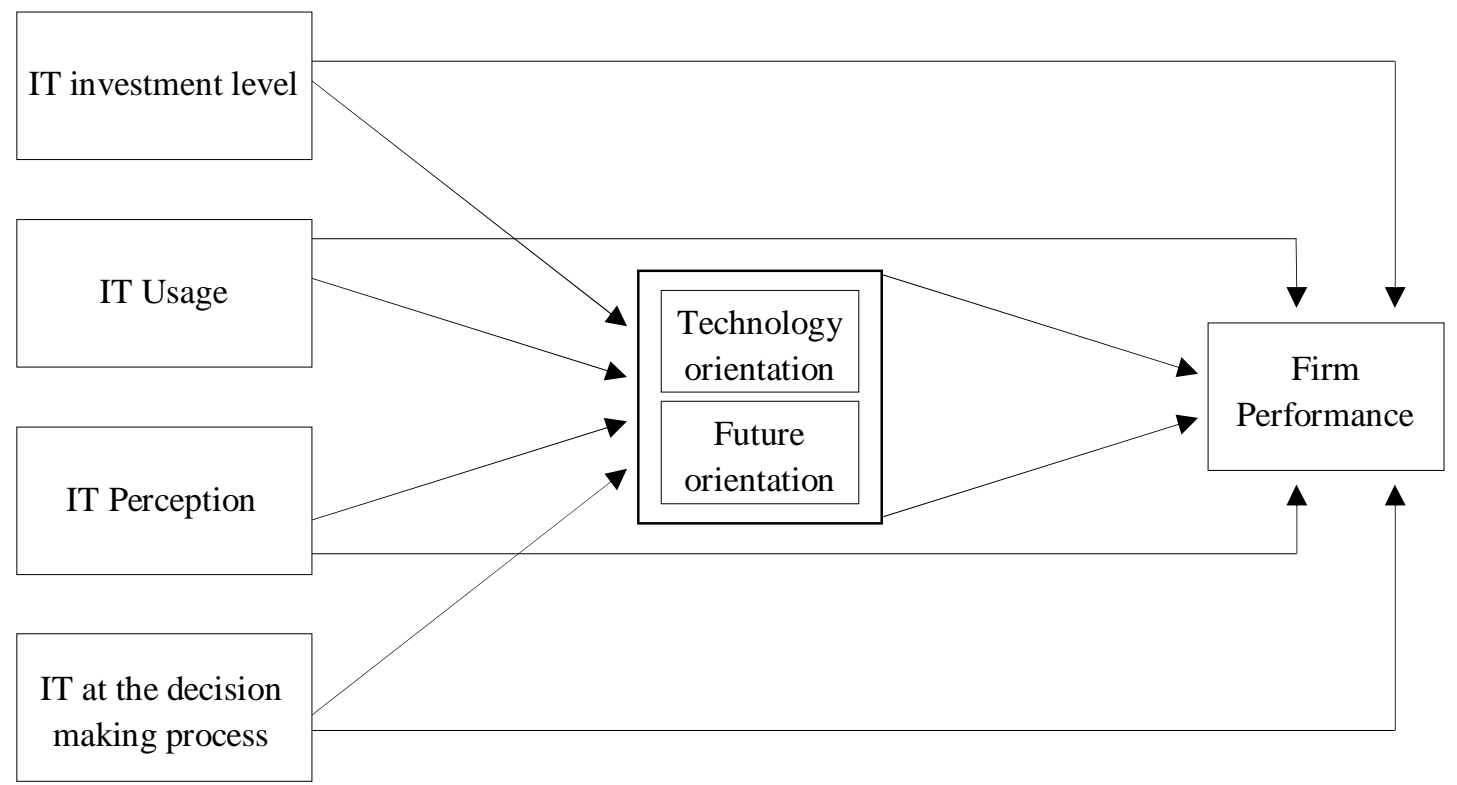

Figure 1: Research Model

\section{METHODOLOGY AND RESULTS}

\section{Sample and Data Collection}

In this study, we gathered data from a sample of different National and Multinational Companies in Turkey which traded on ISE (Istanbul Stock Exchange). Altough firms' instutition level in Turkey is lower than developed countires, the firms which traded on ISE are high. The main reason of choosing this sample is, the instutional firms consider about IT investments at higher degrees.

Firstly, we phoned firms which traded on ISE and gave information about our research. Than, we sent 158 firms which accepted answering questionnaries by e-mail or mail, and 94 of them answered the questionnaires. After investigating the questionnaires; we narrowed our sample with 81 firms which really answered correctly and carefully. Ninety-two percent of the participants were young and middle-aged. Sixty-four percent of the participants were male. Sixty-one percentage of the firms have 250 or above employer. We tested the data with the help of regression analysis and all items included in the questionnaire were measured on a 5-point Likert-type scale. The items that we used were mostly tested in previous research and were proven to be theoretically strong.

\section{Measures}

IT Investment Level: To asses actual IT investment level we used Steve Esselar (2006) 6-item measure.

IT Usage: To asses actual IT usage we used Steve Esselar (2006) 6-item measure.

IT Perception: To asses employees' perception of IT product service we used İlda Tanoglu and Nuri Basoglu (2006) 7-item measure.

IT at makig decision process: To asses employees' decision at the problems and utilize IT technology, we used İlda Tanoglu and Nuri Basoglu (2006) 7-item measure. We searched for the level of firms' technology values and the level of firms' technology trend. 
Technology orientation: We measured technology orientation with using the Barzack (1994) 7-item measure.

Future orientation: We measured future orientation with using the Barzack (1994) 3-item measure. We researched the level of future orientation and the level of future orientation behavior.

Firm Performance: To asses firm performance we constructed measure by combining Lumpkin\&Dess (1996), Antoncic (2003), Zahra (1993), Alpkan (2005).

\section{Factor Analysis}

We used SPSS software 16.00 for the evaluation of our data. Factor analysis, correlation, reliabilty tests, the means of the variable and regression analysis were used to analyze the relationship between variables of the research model.

Varimax rotational, exploratary factor analysis in SPSS software has been used to evaluate factor structure for the variables. We used the Cronbach's Alpha to estimate reliability for scales. These items and factor loadings are presented in Table 1 and Table 2

Table 1: Independent Variable Factor Loadings

\begin{tabular}{|c|c|c|c|c|}
\hline $\begin{array}{l}\text { KMO: }, 855 \\
\text { Explained total variance: } \% 72,243\end{array}$ & $\begin{array}{l}\text { IT decision } \\
\text { making process } \\
\text { (Cronbach } \alpha \text { : } \\
\mathbf{0 , 8 7 3 )}\end{array}$ & $\begin{array}{l}\text { IT level } \\
\text { (Cronbac } \\
\alpha: 0,702)\end{array}$ & $\begin{array}{l}\text { IT } \\
\text { perception } \\
\text { Cronbach } \alpha: \\
\text { 0,781) }\end{array}$ & $\begin{array}{l}\text { IT usage } \\
\text { (Cronbach } \\
\alpha: \mathbf{0 , 7 8 0 )}\end{array}$ \\
\hline $\begin{array}{l}\text { Sharing information and communication by } \\
\text { personnal communication }\end{array}$ & ,759 & & & \\
\hline Collecting data and information & ,832 & & & \\
\hline Develop alternative solutions & ,806 & & & \\
\hline Apply decisions & ,610 & & & \\
\hline We have an informatic department in our firm. & &, 874 & & \\
\hline We have high speed internet network in our firm. & &, 588 & & \\
\hline $\begin{array}{l}\text { The safety of internet security provided by software } \\
\text { support }\end{array}$ & &, 646 & & \\
\hline IT systems usage is easy in our firm & & & ,787 & \\
\hline IT systems are clear in our firm & & & ,848 & \\
\hline $\begin{array}{l}\text { IT deparmant can solve customers' and employers' } \\
\text { needs and problems. }\end{array}$ & & & & ,845 \\
\hline $\begin{array}{l}\text { E-mail is used for external and internal } \\
\text { communication }\end{array}$ & & & &, 532 \\
\hline Software is updated regularly. & & & & ,518 \\
\hline $\begin{array}{l}\text { The speed of internet adjusted by customers' and } \\
\text { employers' ne }\end{array}$ & & & & ,431 \\
\hline
\end{tabular}




\section{Table 2: Dependent Variables Factor Analysis}

\begin{tabular}{|c|c|c|c|}
\hline $\begin{array}{l}\text { KMO: }, 897 \\
\text { Explained total variance: } \% 67,656\end{array}$ & $\begin{array}{l}\text { Technology } \\
\text { Orientation } \\
\text { (Cronbach } \alpha:\end{array}$ & $\begin{array}{l}\text { Future Orientation } \\
\text { (Cronbach } \alpha: 0,866)\end{array}$ & $\begin{array}{l}\text { Firm Performance } \\
\text { (Cronbach } \alpha: 0,945)\end{array}$ \\
\hline $\begin{array}{l}\text { New product idea emerged from technology } \\
\text { orientation }\end{array}$ & 0,638 & & \\
\hline $\begin{array}{l}\text { New products composed of complex process and } \\
\text { technologies }\end{array}$ & 0,870 & & \\
\hline $\begin{array}{l}\text { We used the advanced technolgy while } \\
\text { composing new product }\end{array}$ & 0,652 & & \\
\hline $\begin{array}{l}\text { New product process is directed by technical } \\
\text { personal }\end{array}$ & $\mathbf{0 , 7 1 3}$ & & \\
\hline New technology can be integrate our firm easily. & 0,546 & & \\
\hline Our firm focus future rather than today & & 0,767 & \\
\hline $\begin{array}{l}\text { We give particular importance to researches for } \\
\text { new products for gaining competetive advantage. }\end{array}$ & & 0,767 & \\
\hline We predict future market tendency & & 0,672 & \\
\hline Sales profitability & & & 0,819 \\
\hline Firm's market share growth & & & 0,766 \\
\hline Profitability per customer & & & 0,743 \\
\hline Create a known brand & & & 0,747 \\
\hline Turnover Profitability & & & 0,779 \\
\hline Investment Profitability. & & & 0,736 \\
\hline Growth of Profitability & & & 0,770 \\
\hline Return on Assets & & & $\mathbf{0 , 8 3 0}$ \\
\hline Percentage of the new products & & & 0,706 \\
\hline The number of new products and services & & & 0,623 \\
\hline The number of the new products which get patent & & & 0,622 \\
\hline
\end{tabular}

\section{Correlations between Variables of the Study}

We calculated means and standard deviations for each variable and created a correlation matrix of all variables used in hypothesis testing. Means, standard deviations, reliabilities, and correlations among all scales used in the analyses are shown in Table 3. The means and standard deviations are within the expected ranges.

Correlation analysis is conducted to research the relationship between dependent variables (IT investment level, IT usage, IT perception and IT at making decision process) and independent variables (technology orientation, future orientation and fim performance).

According to correlation analysis; there is a medium relationship between dependent variable technology orientation and IT usage and IT at the making decision process $(\mathrm{p}<0,01)$ and there is a weak 
relationship between technology orientation and IT investment level and IT perception. $(\mathrm{p}<0,01)$.There is a medium relationship between dependent variable future orientation and IT usage, and IT at making decision process, IT investment level and IT perception $(\mathrm{p}<0,01)$.There is a medium relationship between dependent variable firm performance and IT usage, IT at making decision process, IT perception and IT investment level and there is a strong relationship between technology orientation, future orientation and firm performance $(p \ll 0,01)$

According to correlation analysis, all hypotheses are supported.

Table 3: Mean, Standart Deviation and Correlation Coefficient

\begin{tabular}{|l|l|l|l|l|l|l|l|l|l|}
\hline & S.D & MEAN & $\mathbf{1}$ & $\mathbf{2}$ & $\mathbf{3}$ & $\mathbf{4}$ & $\mathbf{5}$ & $\mathbf{6}$ & $\mathbf{7}$ \\
\hline $\begin{array}{l}1 . \text { Des } \\
\text { c }\end{array}$ & 0,6846 & 4,1820 & $(, 873)$ & & & & & & \\
\hline $\begin{array}{l}2 . \text { ITle } \\
\text { v }\end{array}$ & 0,8002 & 4,2057 &, $469(*)$ & $(, 702)$ & & & & & \\
\hline $\begin{array}{l}3 . \text { ITp } \\
\text { er }\end{array}$ & 0,6192 & 4,0308 &, $613(* *)$ &, $302(* *)$ & $(, 781)$ & & & & \\
\hline $\begin{array}{l}4 . \text { ITu } \\
\text { sa }\end{array}$ & 0,6208 & 4,1975 &, $648(* *)$ &, $653(* *)$ &, $385(* *)$ & $(, 780)$ & & & \\
\hline $\begin{array}{l}5 . \text { Tc } \\
\text { or }\end{array}$ & 0,6512 & 3,9629 &, $520(* *)$ &, $365(* *)$ &, $350(* *)$ &, $520(* *)$ & $(, 824)$ & & \\
\hline $\begin{array}{l}\text { 6.Fut. } \\
\text { or }\end{array}$ & 0,7227 & 4,1810 &, $612(* *)$ &, $562(* *)$ &, $509(* *)$ &, $445(* *)$ &, $214(* *)$ & $(, 860)$ & \\
\hline $\begin{array}{l}7 . \text { Fpe } \\
\text { rf }\end{array}$ & 0,7792 & 3,8922 &, $463(* *)$ &, $644(* *)$ &, $499(* *)$ &, $459(* *)$ &, $238(* *)$ &, $523(* *)$ & $(, 945)$ \\
\hline
\end{tabular}

** Correlation is significant at the 0.01 level

$\mathrm{SD}=$ Standard Deviation () Cronbach's alpha

Desc:IT at the making decision stage ITlev:IT investment level ITper: IT perception ITusa:IT usage Tc.or:Technology orientation Fut.or:Future orientation Fperf:Firm performance

\section{Test of the Hypotheses}

The regression tables showed the effects of IT investment level, IT usage, IT at making decision process and IT perception and future orientation and technology orientation on firm performance. The regression models examining the effects of IT investment level, IT usage, IT at the making decision stage and IT perception on future orientation. IT perception $(\mathrm{p}<0.1 ; \beta:, 188)$, IT investment level $(\mathrm{p}<0.001 ; \beta$ : ,316) IT at the making decision stage $(\mathrm{p}<0.001 ; \beta:, 303)$ is statistically significant with future orientation, IT usage does not have a statistically significant effect on future orientation. So, H6, H7, H8 are supported and H9 is not supported. IT at the making decision stage is statistically significant effect on technology orientation $(\mathrm{p}<0.01 ; \beta$ : ,376). So, while H11 is supported; H12, H13 and $\mathrm{H} 14$ are not supported. Future orientation is statistically positively significant with firm performance $(\mathrm{p}<0.01 ; \beta: 405)$. So, H5 is supported. Technology orientation is not statistically significant with firm performance. So, H10 is not supported. IT usage ( $\beta: 236)$ and IT investment level ( $\beta: 347)$ is statistically positively significant with firm performance ( $\mathrm{p}<0.01)$. So, $\mathrm{H} 1$ and $\mathrm{H} 2$ are supported and $\mathrm{H} 3$ and $\mathrm{H} 4$ are not supported. The mediating effects are investigated. The mediating effect of technology has dominated IT usage and decreased the Beta value. Future orientation has shown intermediate variable effect and has dominated IT usage and IT investment level. 
Journal of Global Strategic Management | V. 4 | N. 1 | 2010-June | isma.info | 143-154 | DOI: 10.20460/JGSM.2010415846

\section{Table 4:Regression Analysis Results}

\begin{tabular}{|l|c|c|c|}
\hline & \multicolumn{3}{|c|}{ Dependent Variables } \\
\hline Independent Variables & Future orientation & Technology orientation & Firm Performance \\
\hline IT at decision process &, $303^{* *}$ &, $376^{* * *}$ &,- 164 \\
\hline IT investment level &, $316^{* * *}$ &, 088 &, $236^{* *}$ \\
\hline IT perception &, $188^{*}$ &, 010 &,- 001 \\
\hline IT usage &, 071 &, 149 &, $347^{* * *}$ \\
\hline $\begin{array}{l}\text { Technology } \\
\text { orientation }\end{array}$ &, $405^{* * *}$ & &, 085 \\
\hline Firm performance & F:18,988 & F:8,108 & F: 20,713 \\
\hline & $\mathrm{R}^{2:}, 474$ & $\mathrm{R}^{2}:, 262$ & $\mathrm{R}^{2}:, 627$ \\
\hline
\end{tabular}

$* \mathrm{p}<0.05 ; * * \mathrm{p}<0.01 ; * * * \mathrm{p}<0.001 ;$

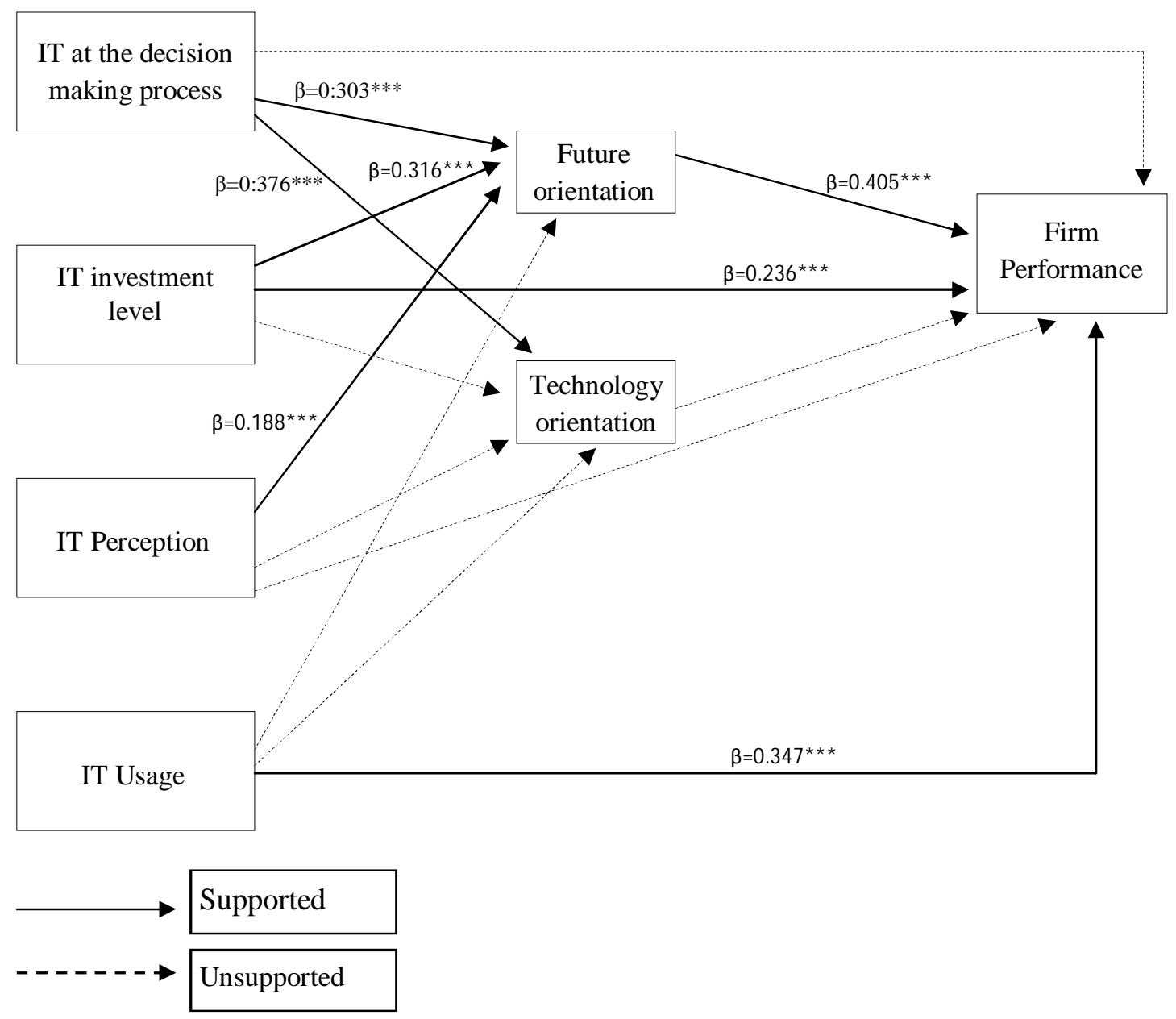

Figure 2: The result of the analyses 


\section{Conclusion and Future Research}

These results should be important to managers and practitioners beside IT researchers; because IT investments have a vital role today's organizations. If the firms manage the investments correctly and carefully, they can manage the market and they can be market leader. The investments' costs are important for organizations. Hence, IT's role in the organizations and maximize the benefits of IT are very important for performance and success of the organizations in the future.

In this study, IT investment level, IT usage, IT at making decision process concepts and their effects on technology orientation, future orientation and firm performance were investigated and a research model was developed.

For analyzing data, SPSS software was used. Firstly, factor analysis was done and questions did not load any factor were eliminated. The reliabilty analysis was done and all variables were reliable. After the reliabilty analysis, correlation analysis were made and all hypotheses were supported according to correlation analysis. There is a medium relationship between dependent variables and independent variables in the hypotheses. In the literature, there is not certain strong relationship between IT investments and firm performance. If IT investments are managed successfully, it can help to increase the firm performance. The relationship between IT investmens and firm performance investigated different aspects in the literature such as type of investments, industry company size, type, company location. (Rotzocki N, Weistroffer H.R; 2009) And Dos Sontos, Kim and Morris found positive relationship between firm performance and IT investmensts. Our research also found a positive relationship between IT usage and IT investment level between firm performance.

When we take future orientation while examining the effects of dependent variables on intermediate variables, the effect of IT usage has dominated the other dependent variables; whereas when we take technology orientation, IT at decision process has dominated the effect of all dependent variables.

The research was done in Turkey- developing country - and the results show that future orientation IT investments have significant positive effect on firm performance. This study can be done in a developed country such as United States and the results can be compared. The questionnaire has been implemented only on firms trading at ISE ( Istanbul Stock Exchange), but can be applied on wider circles at further studies, and firm performance can be evaluated over firms' balance-sheet value. Firm performance can be measured by adding qualitative or quantitive criteria. Performance can be evaluated business process performance such as customer satisfaction, flexibility of process and information sharing. 


\section{REFERENCES}

Akal, Z. 1994: Imalatcı Kamu ve Özel Kesim Kuruluşlarında İşletmeler arası Toplam Performans, Verimlilik, Karlılık ve Maliyet Karşılaştırmaları MPM Yayınları ,Ankara

Antoncic B \& Hisrich R. D 2001: Intrapreneurship: Construct refinement and cross-cultural validation" Journal of Business Venturing,16:5 pp495-527

Atzeni G.E. \& Carboni, O. A 2001: The Economic Effect of Information Technology Firm Level Evidence From the Italian Case. www.crenos.it

Barzack G. 1994: Gaining superior performance of new products in the telecommunications industry, Journal of Business\&Industrial Marketing 9: 19-32

Callahan M. C.\& Gabriel E. A.\& Smith R. E 2009: The Effects of Inter-Firm Cost Correlation, IT Investment, and Product Cost Accuracy on Production Decisions and Firm Profitability Journal of Information Systems, 23: 51-78

Davis, F. D 1986: A technology acceptence model for emprically testing new end-user information systems: Theory and Results, Doctoral Dissertation; Massachusetts Institute of Technology

Dehning B.\& Richardson V.J. \& Stratopoulos 2005: Information technology investments and firm value Information\&Management, 42:989-1008

Dos Santos \&, B.L., Peffers\& K. \&Mauer, D. "The Impact ofInformation Technology Investment Announcements on the Market Value of the Firm," Information Systems Research $4: 1-23$.

Grant R.M. 1995: Contemporary Strategy Analysis, Blackwell Publishers Inc., Oxford, UK

Hu Q \& Quan J. 2004: Evaluating the impact of IT investments on productivity: a casual analysis at industry level, International Journal of Information Management. 25, 39-53

Huang S.M\& Ou.C.S\&Chen C.\&Lin B 2006: An empirical study of relationship between IT investment and firm performance: A resource-based perspective European Journal of Operation Management, 173: 984-999

Hunt S.D \& Morgan R.M. 1996: The Resource-Advantage of Competition: Dynamics, Path Dependencies, and Evolutionary Dimensions," Journal of Marketing, 60, 107-114

Iraz R. 2008: Organizasyonlarda Karar Verme ve İletişim Sürecinin Etkinliği Bakımından Bilgi

Teknolojilerinin Rolü, Selçuk Üniversitesi Karaman İktisadi ve İdari Bilimler Fakültesi

Kim J.K.\& Xiang J.Y. \& Lee S. 2009: The impact of IT investment on firm performance in China: An empirical investigation of the Chinese electronics industry Technical Forecasting\&Social Change, 73, 678-687

Kraut, R. 1998: Internet Paradox: A Social Technology That Reduces Social Involvement and Psychological Well-Being?, American Psychologist, 53 (9): 1017-1031

Lumpkin G.T. \& Dess G.G. 1996: Clarifying the entrepreneurial orientation construct and linking it to performance, Academy of Management Review 21: 135-172

Morris, S.A. and Strickland, T.H. 2008: Exploration of Information System Process Improvements and Firm

Performance, Journal of Computer Information Systems49: 86-91.

Oh, W., Kim, J.W., and Richardson, V.J. 2006: The ModeratingEffect of Context on the Market Reaction to IT Investments, Journal of Information Systems 20:.19-44.

RMS 2008: “The IT Investment Management Approach”, Resource Management Systems 
Roztocki N. \& Weistroffer H.R. 2009: Information technology investments: Does activity based costing matter? Journal of Computer Information Systems Winter 2009

Ta.B \&Te.M. 1997: "Relating Information Technology Investment to Organizational Performance a Causal Model Analysis" International Journal Management Science , 25:43-56

Tanoglu I. \& Basoglu N 2005: Exploring the relationship between information technology diffusion and managerial decision making" Proocedings of PICMET'05

Wen, H.J. \& Sylia, C. 1999: A Roak Map for the Evaluation of Information Technology Investment, Eds Mahmood, M.A. \& Szewchzak, E. J., Measuring Information Technology Payoff:

Contemporary Approaches; Idea Group

Yao L. \& Sutton S. \& Chan S. (2009): Wealth Creation From Information Technology Investments Using the Eva, Journal of Computer Information Systems, Winter

Zahra S. A 1993: Environment, corporate entrepreneurship and financial performance: A taxonomic approach. Journal of Business Venturing 8: 319-340

Zehir C. \& Yilmaz E. \& Velioglu H. 2008: The Impact of Information Technology Practices and Organizational Learning on Firm Innovation and Performance, Journal of Global Strategic Management 2:24-37 